\title{
Pendampingan Anak Korban Kekerasan dan Eksploitasi Seksual Melalui Trauma Healing dengan Media Teater di Kota Surakarta
}

\author{
Nining Sholikhah \\ Politeknik Pratama Mulya Surakarta \\ Yayasan KAKAK. \\ Yayasan Pusat Studi Anak Bocah Pintar Karanganyar \\ E-mail: sholikhahnining@gmail.com
}

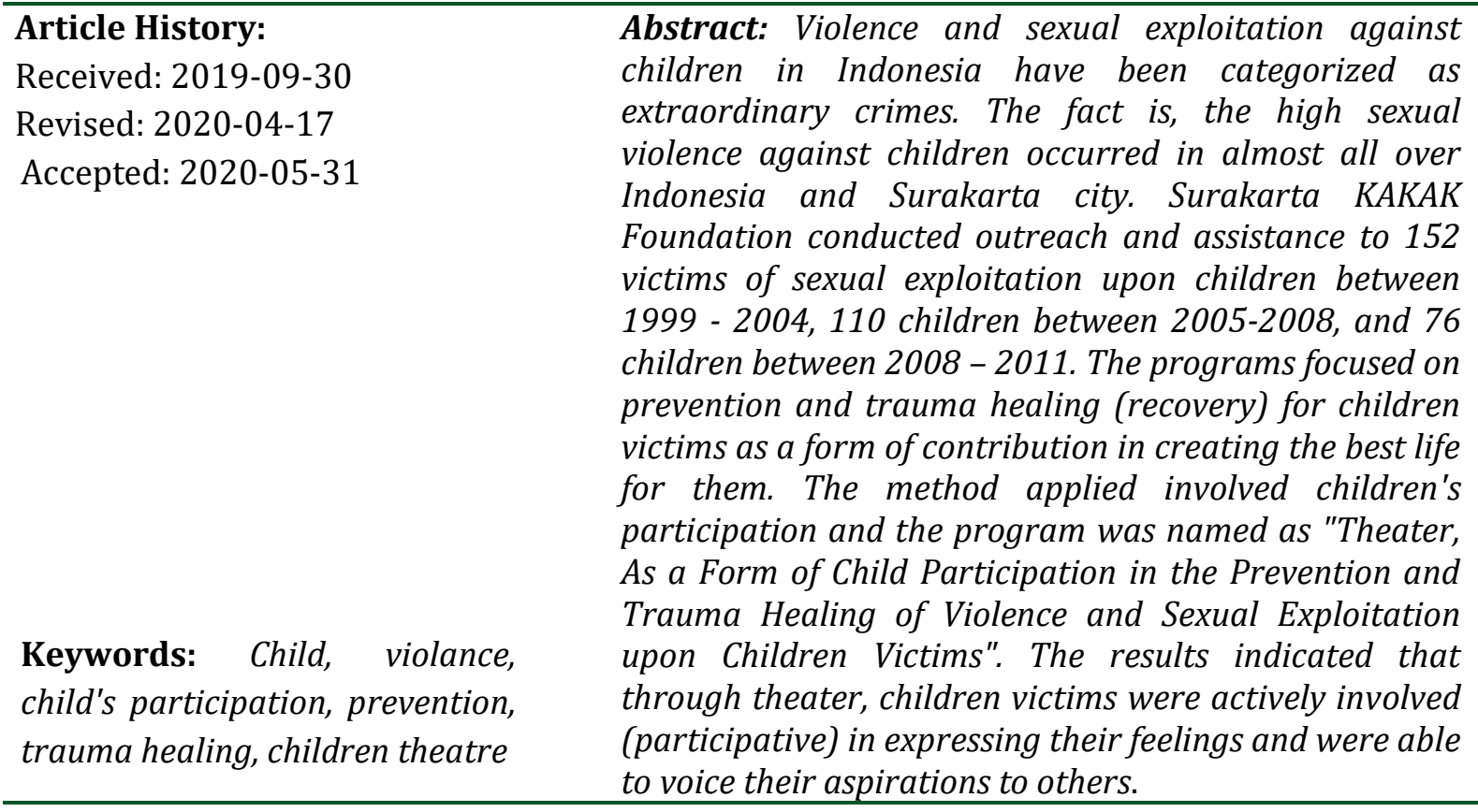

\section{Pendahuluan}

Anak adalah seorang yang belum berusia 18 (delapan) belas tahun, termasuk anak yang masih dalam kandungan. Meskipun secara fisik masih kecil dan lemah, anak harus dipandang sebagai manusia seperti layaknya manusia dewasa. Untuk itulah, anak harus mendapatkan perlindungan. Perlindungan Anak adalah segala kegiatan untuk menjamin dan melindungi Anak dan hak-haknya agar dapat hidup, tumbuh, berkembang, dan berpartisipasi secara optimal sesuai dengan harkat dan martabat kemanusiaan, serta mendapat perlindungan dari kekerasan dan diskriminasi ${ }^{1}$.

1 Presiden Republik Indonesia, Undang-Undang Republik Indonesia Nomor 35 Tahun 2014 Tentang Perubahan Atas Undang-Undang Nomor 23 Tahun 2002 Tentang Perlindungan Anak (Jakarta, Indonesia, 2014). 
Kekerasan seksual adalah tindakan yang mengarah pada ajakan seksual dengan paksaan atau tanpa persetujuan. Ajakan seksual pada anak juga dapat dikategorikan sebagai bentuk kekerasan seksual, karena anak merupakan individu yang belum memiliki pilihan sadar untuk menyatakan persetujuan tersebut. Maka kekerasan seksual yang disertai dengan eksploitasi pada anak merupakan kejahatan kemanusiaan. Karena selain merugikan secara ekonomi dan sosial, kekerasan seksual pada anak memiliki implikasi hancurnya martabat anak².

Kekerasan seksual dapat diartikan sebagai "bentuk kontak seksual atau bentuk lain yang tidak diinginkan secara seksual." oleh sebab itu, kekerasan seksual cenderung disertai tekanan psikologis atau fisik. Sebagian ahli membedakan perkosaan dengan kekerasan seksual karena dianggap spesifik dimana perkosaan didefinisikan sebagai penetrasi seksual tanpa izin atau dengan paksaan, bisa disertai dengan kekerasan fisik. Dengan demikian, kekerasan seksual bisa juga dipahami dengan pemaksaan kontak seksual secara tidak wajar atau semua hal yang dimaksudkan untuk menstimulasi secara seksual ${ }^{3}$.

Kekerasan seksual terhadap anak di Indonesia telah masuk kategori kejahatan luar biasa. Kekerasan seksual terhadap anak mengalami kecenderungan yang terus meningkat. Data dari Komnas Perlindungan Anak (Komnas PA) menyebutkan bahwa pada tahun 2012 jumlah kekerasan terhadap anak adalah 2.637 dan 41\% diantaranya adalah kekerasan seksual. Pada tahun 2013, jumlah kasus kekerasan terhadap anak adalah 1.032 dan 52\% diantaranya adalah kekerasan seksual. Pada tahun 2014 jumlah kekerasan terhadap anak adalah 1.039, dan 60\% diantaranya adalah kekerasan seksual.

Fakta memprihatinkan yang lain, tentang kekerasan seksual terhadap anak adalah eksploitasi seksual komersial pada anak (ESKA). ESKA dapat diartikan sebagai suatu bentuk pengeksploitasian terhadap anak yang dilakukan secara seksual untuk kepentingan komersial. Secara definitif, ESKA dapat dijelaskan sebagai "penggunaan anak untuk tujuan seksual dengan imbalan tunai atau dalam bentuk lain antara anak, pembeli jasa seks, perantara atau agen, dan pihak lain yang memperoleh keuntungan dari perdagangan seksualitas anak tersebut"4.

Ada tiga bentuk ESKA. Pertama, prostitusi anak, yaitu penggunaan anak dalam kegiatan seksual dengan pembayaran atau imbalan dalam bentuk lain. Kedua, pornografi anak, yaitu setiap representasi, dengan sarana apa pun, pelibatan secara eksplisit seorang anak dalam kegiatan seksual baik secara nyata maupun disimulasikan, atau setiap representasi dari organ-organ seksual anak untuk tujuan seksual. Ketiga,

\footnotetext{
2 Muh Barid Nizarudin Wajdi, “Trauma Healing Pada Penderita Depresi Di Nganjuk," Janaka, Jurnal Pengabdian Masyarakat 1, no. 2 (2019): 27-32.

3 Davit Setyawan, "Lindungi Anak Indonesia Dari Kekerasan Seksual," Komisi Perlindungan Anak Indonesia.

4 Presiden Republik Indonesia, Keputusan Presiden RI No. 87 Tahun 2002 Tentang Rencana Aksi Nasional (RAN) Penghapusan Eksploitasi Seksual Komersial Anak (Indonesia, 2002).
} 
perdagangan anak untuk tujuan seksual, sebagaimana dirumuskan dalam pasal 3 (tiga) Protokol untuk Mencegah dan Menghukum Perdagangan Manusia, terutama Perempuan dan Anak ${ }^{5}$. Pelacuran anak, merupakan salah satu bentuk ESKA. Dalam Penelitian UNICEF tentang Partisipatif Anak yang Dilacurkan di Surakarta dan Indramayu pada tahun 2002, data anak yang dilacurkan di Surakarta adalah 24 orang. Pemetaan anak yang dilacurkan pada tahun 2004, di Surakarta ditemukan ada 117 anak yang dilacurkan ${ }^{6}$.

Yayasan KAKAK pernah juga melakukan penelitian tentang Anak Yang Dilacurkan (AYLA) di kota Surakarta pada tahun 2000 yang menjangkau 50 anak yang dilacurkan. Penelitian ini memberi gambaran bahwa AYLA yang berada di kota Surakarta tidak saja berasal dari Kota Solo, tetapi juga dari kabupaten yang lain di Eks Karesidenan Surakarta. Sebaran anak yang dilacurkan (AYLA) meliputi: 28 anak berasal dari Kota Surakarta, 11 anak dari Kabupaten Wonogiri, 5 anak dari Boyolali, 3 anak dari Sukoharjo dan 3 anak dari Klaten. Dalam kegiatan penjangkauan dan pendampingan yang dilakukan Yayasan KAKAK Surakarta terhadap anak korban eksploitasi seksual, besaran jumlah anak yang dilacurkan adalah sebagai berikut: pada tahun $1999-2004$ sejumlah 152 anak, pada tahun 2005 - 2008 sejumlah 110 anak dan pada tahun 2008 2011 sejumlah 76 anak.

Kekerasan dan eksploitasi seksual pada anak berimplikasi munculnya trauma fisik dan psikis. Trauma fisik adalah situasi yang terjadi pada seseorang yang berkaitan dengan cedera fisik, kerusakan jaringan, luka atau shock. Sedangkan trauma secara psikologis diartikan sebagai kecemasan hebat dan mendadak akibat peristiwa di lingkungan seseorang yang melampaui batas kemampuannya untuk bertahan, mengatasi atau menghindar ${ }^{7}$. Hasil pemeriksaan medis (Yayasan KAKAK, 2000), sebagian besar anak korban eksploitasi seksual menderita penyakit menular seksual. Anak-anak juga mengkonsumsi minuman keras dan dan obat-obatan terlarang, biasanya sejenis pil ekstasi. Sedangkan trauma psikis yang ditimbulkan akibat kekerasan dan eksploitasi seksual berupa korban mengalami tekanan jiwa yang amat berat, karena selalu teringat peristiwa kekerasan seksual yang dialaminya. Korban merasa peristiwa itu membayanginya secara terus menerus. Korban juga mengalami rasa percaya diri yang hilang dan timbul perasaan dikucilkan dari masyarakat/teman karena merasa diri mereka telah "kotor".

Trauma yang dialami korban kekerasan seksual adalah situasi kritis dan harus segera memperoleh penanganan untuk pemulihan. Trauma yang dialami anak korban

\footnotetext{
${ }^{5}$ Presiden Republik Indonesia, Undang-Undang Republik Indonesia Nomor 14 Tahun 2009 Tentang Pengesahan Protokol Untuk Mencegah, Menindak, Dan Menghukum Perdagangan Orang, Terutama Perempuan Dan Anak-Anak, Melengkapi Konvensi Perserikatan Bangsa-Bangsa Menentang Tindak Pidana Transnasio (Indonesia, 2009).

${ }^{6}$ Team Peneliti UNICEF Indonesia, Partisiasi Anak Indonesia : Harapan Dan Impian (Jakarta, 2005).

7 Endah Nawangsih, "Play Therapy Untuk Anak-Anak Korban Bencana Alam Yang Mengalami Trauma (Post Traumatic Stress Disorder/Ptsd)," Psympathic: Jurnal Ilmiah Psikologi 1, no. 2 (2014): 164-178.
} 
kekerasan dan eksploitasi seksual yang tidak terpulihkan dapat melahirkan pendendam dan berkecenderungan menjadi pelaku kekerasan seksual. Akhirnya akan mewujud menjadi kekerasan turunan atau budaya kekerasan pada anak.

Berdasarkan penjelasan tersebut, maka upaya perlindungan anak yang dilacurkan salah satunya melalui media "Teater" yang diinisiasi oleh Yayasan KAKAK, sebuah Lembaga Swadaya Masyarakat (LSM) yang telah berdiri pada 1997 di kota Surakarta, bergerak dalam perlindungan anak dari kekerasan dan eksploitasi seksual. Teater ini dikembangkan untuk mengembangkan Partisipasi Anak dalam Pencegahan dan Trauma Healing Anak Korban Kekerasan dan Eksploitasi Seksual.

\section{Metode}

Kegiatan pendampingan anak dari kekerasan dan eksploitasi seksual, Yayasan KAKAK Surakarta menggunakan metode partisipatif melalui media teater. Tujuan digunakan metode partisipatif, karena hal ini terkait dengan landasan kerja organisasi yang bergerak dalam isue anak, yakni Konvensi Hak Anak (KHA). Konvensi Hak Anak adalah pasal 12, yang menjelaskan bahwa : Negara Peserta akan menjamin anak-anak yang mampu membentuk pandangannya sendiri, bahwa mereka mempunyai hak untuk menyatakan pandangan-pandangannya secara bebas dalam semua hal yang mempengaruhi anak, dan pandangan anak dipertimbangkan sesuai dengan usia dan kematangan anak. Untuk tujuan ini, anak secara khusus akan diberi kesempatan untuk didengar dalam setiap proses peradilan dan administratif yang mempengaruhi anak, baik secara langsung, atau melalui suatu perwakilan atau badan yang tepat dengan cara yang sesuai dengan hukum secara nasional ${ }^{8}$.

Partisipasi Anak adalah Keterlibatan seseorang yang belum berusia 18 tahun dalam proses pengambilan keputusan tentang segala sesuatu yang berhubungan dengan dirinya dan dilaksanakan atas kesadaran, pemahaman serta kemauan bersama sehingga anak dapat menikmati hasil atau mendapatkan manfaat dari keputusan tersebut ${ }^{9}$.

Untuk mengukur tingkat partisipasi, dapat menggunakan model tangga partisipasi Roger Hart. Roger Hart mengidentifikasi level partisipasi menjadi 8 level dan menyebutnya The Ladder of participation ${ }^{10}$. The ladder of participation tersebut meliputi: (1) Manipulasi (manipulation), dalam level ini, anak tidak mengetahui dan memahami konsep program yang akan dilakukan, dan apa saja yang akan dilakukan.

\footnotetext{
${ }^{8}$ pasal 12 dalam United Nations, Convention on the Rights of the Child Text, 1989.

${ }_{9}^{9}$ Menteri Negara Pemberdayaan Perempuan dan Perlindungan Anak Republik Indonesia, Peraturan Menteri Negara Pemberdayaan Perempuan Dan Perlindungan Anak Republik Indonesia, Nomor 3 Tahun 2011, Tentang Kebijakan Partisipasi Anak Dalam Pembangunan (Indonesia, 2011).

${ }^{10}$ R A Hart, "Children's Participation: From Tokenism to Citizenship (UNICEF International Child Development Centre. Spedale Degli Innocenti. Firenze, Italy)" (1992).
} 
Anak diberitahu akan tetapi tidak dimintai pendapat; (2) Dekorasi, bentuk partisipasi anak dalam level ini adalah memberikan hiburan, akan tetapi anak tidak memahami konsep dan apa yang akan dilakukan; (3) Tokenisme, dalam level ini, anak-anak di undang untuk mengikuti pertemuan, misalnya adalah konferensi atau peretmuan untuk memutuskan sesuatu persoalan yang terkait dengan anak. Mereka datang mewakili anak-anak, akan tetapi tidak diberi kesempatan untuk menyampaikan pendapat maupun untuk memutuskan; (4) Assigned but informed (ditetapkan tetapi diberi informasi), dalam level ini, program dibuat atau diinisiasi oleh orang dewasa, anak-anak mengerti akan program yang akan atau sedang dilakukan; (5) Consulted and informed (Diberi informasi dan nasehat), dalam level ini, program dibuat atau diinisiasi oleh orang dewasa, dan anak mengetahui akan program ini. Ide-ide anak menjadi bahan pertimbangan dalam pembuatan keputusan program; (6) Adult initiated - shared dicisions with children, keputusan atas inisiatif orang dewasa dan dilakukan bersama anak. Setiap perencanaan dan pelaksanaan program, pengambilan keputusan selalu didiskusikan dengan anak-anak; (7) Child - initiated and directed (Anak diberi inisiatif dan diarahkan), anak-anak bisa membuat perencanaan program dan menjalankannya sendiri. Orang dewasa berperan dalam memberikan konsultasi dan membiarkan anakanak menjalankan program mereka sendiri; dan (8) Child - initiated shared dicisions with adult, keputusan atas inisiatif anak, dilakukan bersama orang dewasa. Level kedepalan ini merupakan level tertinggi dalam partisipasi anak, dengan model Hard. Dalam level ini anak-anak dengan orang dewasa bersama-sama merencanakan, melaksanakan, dan mengelola program.

\section{Teater Sebagai Alat Kampanye dan Trauma Healing}

Pendekatan yang digunakan dalam program ini adalah dengan menggunakan teater. Teater yang digunakan dalam menjalankan program tersebut memiliki 2 (dua) fungsi. Pertama, teater sebagai medium untuk menyampaikan pesan tentang STOP Kekerasan dan eksploitasi seksual pada anak. Pada ranah ini teater berfungsi sebagai alat kampanye. Kedua, teater sebagai medium katarsis bagi anak-anak korban kekerasan seksual komersial. Pada ranah ini, teater menjadi media atau alat trauma healing bagai anak-anak korban kekerasan seksual komersial.

Menurut Leslie B. Snyder, kampanye merupakan aktivitas komunikasi yang terorganisasi, secara langsung ditujukan kepada khalayak tertentu, pada periode waktu yang telah ditetapkan untuk mencapai tujuan tertentu ${ }^{11}$. Teater sebagai alat kampanye dapat dilihat dari lakon atau materi pentas teater, alur cerita, cara pesan disisipkan dalam pertunjukan, pemilihan lokasi pertunjukan dan pemaknaan setelah pertunjukan dilakukan. Dalam meramu pertunjukan teater, materi yang diangkat di atas panggung tidak pernah keluar dari adalah materi tentang perlindungan anak. Materi ini

11 Yana Erlyana, “Kajian Kampanye Sosial Hemat Air,” Rupa Rupa 4, no. 2 (2017)..

, 
diambilkan dari pengalaman riel anak-anak korban. Pentas teater dilakukan di tempat terbuka dan terbuka untuk umum. Pertunjukan teater selalu disertai dengan sarasehan dengan mengundang narasumber ahli yang akan membedah isu yang diangkat di atas panggung. Pertunjukan teater secara khusus mengundang stakeholder yang berkompeten dalam perlindungan anak.

Teater yang dikembangkan oleh Yayasan KAKAK dapat juga disebut sebagai play therapy, yakni bermain peran dalam upaya trauma healing korban kekerasan seksual. Terapi bermain ini sangat berguna dalam upaya pemulihan pada anak yang mengalami trauma. Biasanya terapis memakai permainan untuk memulai topik yang tidak dapat dimulai secara langsung. Menurut The Association for Play Therapy, terdapat 14 macam keuntungan yang diperoleh bila menggunakan play therapy sebagai sebuah intervensi, sebagaimana tersaji dalam table berikut:

Tabel 1. Macam-macam Play Therapy

\begin{tabular}{|c|c|c|}
\hline No & Play Therapy & Keterangan \\
\hline 1 & $\begin{array}{l}\text { Mengatasi } \\
\text { resistensi }\end{array}$ & $\begin{array}{l}\text { Anak-anak biasanya sulit untuk diajak konsultasi dengan } \\
\text { konselor, apalagi mempunyai keinginan sendiri. Permainan } \\
\text { adalah salah satu cara untuk menarik anak agar bisa terlibat } \\
\text { dalam kegiatan konseling. }\end{array}$ \\
\hline 2 & Komunikasi & $\begin{array}{l}\text { Permainan adalah media alami yang digunakan anak untuk } \\
\text { mengeskpresikan dirinya. Konselor bisa menggunakan } \\
\text { berbagai pilihan permainan yang dapat memancing anak } \\
\text { untuk dapat terus terlibat dalam permainan. }\end{array}$ \\
\hline 3 & Kompetensi & $\begin{array}{l}\text { Bermain memberikan kesempatan bagi anak untuk } \\
\text { memenuhi kebutuhan anak untuk mengeksplorasi dan } \\
\text { menguasai se-suatu keterampilan. Konselor bisa } \\
\text { membangun kepercayaan dengan menunjukkan bahwa anak } \\
\text { sedang melakukan kerja keras dan menunjukkan kemajuan }\end{array}$ \\
\hline 4 & Berfikir Kreatif & $\begin{array}{l}\text { Keterampilan problem solving dikembangkan, sehingga } \\
\text { pemecahan atas persoalan anak bisa tercapai. Permainan } \\
\text { memberikan peluang yang besar bagi anak untuk } \\
\text { mengembangkan kemampuan diri untuk berpikir kreatif } \\
\text { atas persoalan yang dialami }\end{array}$ \\
\hline 5 & Chatarsis & $\begin{array}{l}\text { Melalui permainan anak-anak dapat menyampaikan tekanan } \\
\text { emosi yang dialaminya dengan lebih bebas, sehingga anak- } \\
\text { anak bisa tumbuh dan berkembang secara optimal tanpa } \\
\text { beban mental. }\end{array}$ \\
\hline 6 & Abreaction & $\begin{array}{l}\text { Dalam bermain, anak mendapat kesempatan untuk } \\
\text { memproses dan menyesuaikan kesulitan yang pernah } \\
\text { dialami secara simbolis dengan ekspresi emosi yang lebih } \\
\text { tepat }\end{array}$ \\
\hline 7 & Role playing & $\begin{array}{l}\text { Anak dapat mempraktekkan berbagai tingkah laku yang } \\
\text { baru dan mengembangkan kemampuan empati dengan } \\
\text { orang lain }\end{array}$ \\
\hline 8 & Fantacy & imajinasinya untuk \\
\hline
\end{tabular}


mengerti akan pengalamannya yang menyakitkan. Mereka juga bisa mencoba mengubah hidup mereka secara perlahanlahan

9 Metaphoric Anak-anak dapat memperoleh pengertian yang mendalam teaching atas kesulitan dan ketakutan yang dialaminya dengan kiasan yang dimunculkan dalam permainan

10 Attachment Anak dapat mengembangkan suatu ikatan dengan konselor formation serta mengembangkan kemampuan untuk membangun koneksi dengan orang lain

11 Peningkatan Bermain dapat meningkatkan hubungan terapi yang positif, hubungan memberikan kebebasan anak untuk mewujudkan aktualisasi diri dan tumbuh semakin dekat dengan orang lain disekitarnya. Anak dapat mengenal cinta dan perhatian yang positif terhadap lingkungannya

12 Emosi positif Anak-anak menikmati permainan, dengan suasana hati ini mereka bisa tertawa dan mempunyai waktu yang menyenangkan di tempat yang mereka merasa diterima

13 Menguasai ketakutan

Dengan permainan yang diulang-ulang akan mengurangi kegelisahan dan ketakut-an anak. Bekerja dengan mainan, seni dan media bermain lainnya mereka akan menemukan berbagai keterampilan dalam mengatasi ketakutan

14 Bermaingame Game membantu anak untuk bersosialisasi dan mengembangkan kekuatan egonya. Mereka mempunyai peluang untuk meningkatkan keterampilan

\section{Hasil}

Mengorganisir anak-anak korban kekerasan dan eksploitasi seksual tidak semudah mengorganisir komunitas yang lain. Komunitas anak-anak ini memiliki keunikan tersendiri. Apalagi pada anak korban yang mengalami traumatik. Pada umumnya anak-anak yang mengalami kondisi trauma menunjukkan simptom-simptom seperti ketakutan, cemas, sedih, menghindar dan kurang responsif terhadap beragam emosi. Untuk menjangkau anak-anak korban kekerasan dibutuhkan taktik jitu dan pola komunikasi khusus, bahkan untuk memasuki wilayah isue ini perlu 'kata kunci'. Tanpa mengetahui 'kata kunci', seorang organiser akan tersesat dan larut dalam situasi yang tidak berujung pangkal.

Dalam bagian ini, penulis akan memaparkan langkah-langkah pengorganisasian dalam menjalankan program Yayasan Kakak dan sekaligus menceritakan trik-trik di lapangan. Langkah-langkah yang dilakukan adalah:

\section{Persiapan Sosial}

Sebelum kegiatan teater dilakukan, Tim Yayasan KAKAK melakukan persiapan sosial. Persiapan sosial dilakukan untuk melakukan prakondisi membangun partisipasi anak korban kekerasan dan eksploitasi seksual yang dilakukan dalam beberapa 
tahapan:

1. Persiapan Tim

Persiapan Tim dilakukan dengan tahapan:

Pertama, membentuk kelompok kerja dan menyusun protokol. Karena yang dihadapi adalah anak anak korban yang memiliki sifat-sifat khusus, maka Tim juga harus khusus dan harus memegang nilai-nilai khusus. Salah satu nilai yang harus dipegang adalah larangan keras melakukan child abuse atau menggunakan anak anak dampingan sebagai pacar untuk kepuasan seksual.

Kedua, mempelajari sosiologi anak korban dan AYLA. Komunitas ini memiliki lingkungan dan tata nilai yang dianut tersendiri. Mempelajari sosiologi kehidupan mereka menjadi prasyarat utama, sebelum menjalankan kerja penjangkauan dan pengorganisasian. Yayasan KAKAK harus mendatangkan nara sumber ahli dalam hal ini.

Ketiga, berlatih komunikasi termasuk mengenali kata kunci untuk memasuki dunia yang gelap namun penuh dengan gemerlap.

2. Penjangkauan dan menemukan Informan Kunci

Dibutuhkan waktu dan keberanian ekstra untuk menemukan informan kunci. Karena dunia AYLA layaknya dunia mafia. Setiap anak yang masuk dunia AYLA memiliki broker atau germo. Dan seringkali germo yang ada juga seusia anak-anak dan bahkan pacar dari AYLA.

Trik yang dilakukan Tim Yayasan KAKAK adalah menongkrongi tempat-tempat yang biasa dipakai mangkal AYLA. Komunikasi dilakukan layaknya seorang pelanggan atau bahkan layaknya pelaku prostitusi dewasa. Sampai pada titik meeting of mind dengan seorang AYLA, maka langkah selanjutnya lebih mudah. Seseorang inilah yang kemudian menjadi pintu dan ujung tombak penjangkauan. Dalam Yayasan KAKAK disebut dengan Tutor Sebaya.

Tutor sebaya inilah kunci masuk ke dalam komunitas Anak Korban kekerasan dan eksploitasi seksual. Untuk menjadikan seseorang sebagai Tutor Sebaya haruslah memenuhi kriteria khusus, yakni mereka yang berkeinginan kuat untuk keluar dari situasi dan kondisi (sebutlah pelacuran anak), memiliki rasa persaudaraan yang kuat, dan memiliki semangat voluntarism (baca: kerelawanan)

3. Memahami Situasi melalui bantuan tutor sebaya

4. Penjangkuan korban lebih luas

Setelah ketemu Tutor Sebaya, maka penjangkuan lebih luas cukup mudah dilakukan. Sampai pada suatu titik, anak-anak korban ini bersedia dipertemukan dalam forum lebih besar dan diformat menjadi kelompok anak. 


\section{Pembentukan Kelompok Teater}

Anak usia 14 - 18 tahun, adalah masa dimana ketergantungan anak dengan temannya cukup tinggi. Pada masa ini seringkali anak-anak menghabiskan waktu bersama dengan teman-teman sebayanya. Dalam proses interaksi dengan teman sebaya ini, seorang anak akan belajar dari temannya, anak akan melakukan komunikasi dengan temannya, memberi masukan sekaligus menerima masukan. Seringkali anak-anak lebih percaya kepada teman daripada kepada orangtua atau guru di sekolah. Di sinilah ada tutor sebaya. Dengan adanya tutor dan teman sebaya, pola komunikasi dalam berjalan dengan efektif. Setelah kelompok anak mulai terbentuk, mulailah diajukan tawaran untuk kegiaan teater.

Dalam program ini, anak korban yang dilibatkan dalam program adalah anak usia 14 - 18 tahun. Anak-anak ditempatkan sebagai subyek utama, yaitu sebagai warga negara yang mampu berpartisipasi dalam program yang berpengaruh bagi kehidupan dan lingkungannya. Anak-anak mengikuti program ini dengan kesadaran mereka sendiri, hal ini dinyatakan dengan pengisian lembar kesediaan anak.

Kegiatan teater ini menggunakan prinsip kerelawanan, kesenangan dan kesadaran diri. Bagi anak-anak yang tidak mau berpartisipasi dalam kegiatan teater tidak dipaksa ikut, namun tidak boleh dikucilkan. Anak-anak yang tidak tergabung dalam kegiatan teater tetap diberi kesempatan untuk melihat latihan, ikut sarasehan dan juga diberi kesempatan untuk menyaksikan pertunjukan.

Melalui pembentukan kelompok anak ini, koordinasi mudah dilakukan.

"........ Kelompok teater Pelangi sudah memiliki pengurus yang bertugas mengkoordinir pelaksanaan kegiatan. Pelangi menuju mandiri dengan belajar mengelola sendir pementasan baik dari persiapan sampai pada evaluasi dan pembuatan anggaran pentas.........".12

Melalui kelompok ini pula, anak-anak mengawali belajar berorganisasi yang baik. Karena melalui kelompok ini, anak-anak belajar untuk berbagi tugas, tanggungjawab dan kewenangan. Kelompok teater yang dibentuk bernama Kelompok Teater Pelangi.

\section{Workshop Anak}

Setelah kelompok teater pelangi terbentuk, maka dilakukan pertemuan rutin dalam bentuk workshop. Atau dalam istilah anak korban kekerasan dan eksploitasi seksual adalah sekolah teater. Peserta Workshop adalah anak-anak korban kekerasan dan eksploitasi seksual. Sedangkan Tim program Yayasan KAKAK berperan sebagai fasilitator workshop. Ada beberapa workshop yang dilakukan kelompok teater, sebagai

12 Nining Sholikah, Partisipasi Anak Pada Perlindungan Anak Yang Dilacurkan (AYLA); Studi Program Perlindungan Anak Di Yayasan KAKAK Di Surakarta (Surakarta, 2008). 
berikut:

1. Workshop Awal

Workshop awal ini ditujukan untuk menyamakan persepsi tentang kegiatan teater. Dalam workshop awal dibahas tentang tujuan dalam kegiatan teater, tujuan pementasan teater dan apa keuntungan yang dapat diperoleh dalam kegiatan teater.

Workshop awal tidak hanya dilaksanakan sekali, namun beberapa kali untuk menginternalisasi bahwa teater penting bagi kelompok anak korban kekerasan dan eksploitasi seksual.

2. Workshop Penyusunan Lakon Cerita

Workshop penyusunan lakon cerita dilaksanakan setelah kelompok bersepakat untuk melakukan pertunjukan. Alur atau agenda workshop penyusunan lakon cerita adalah sebagai berikut:

a. Merumuskan Judul Pertunjukan. Workshop dimulai dengan melakukan penggalian gagasan dan ide cerita. Tentu ide cerita tidak akan keluar dari thema besar program, yakni perlindungan anak dari kekerasan dan eksploitasi seksual. Anak korban kekerasan dan ekploitasi seksual memulai penggalian gagasan dengan menceritakan pengalaman hidupnya, baik pengalaman yang pahit maupun pengalaman menyenangkan, sekaligus harapan-harapan kehidupan mendatang. Seorang fasilitator meramu pengalaman hidup mereka menjadi judul pertunjukan.

b. Merumuskan Tangga dramatik. Setelah judul pertunjukkan disepakati, anakanak difasilitasi untuk merumuskan garis-garis besar cerita dan alur tangga dramatik. Dalam penyusunan tangga dramatik ini, Yayasan KAKAK dibantu oleh penggiat teater Gidag Gidig ${ }^{13}$ dari Solo. Secara substansial tidak begitu sulit merumuskan tangga dramatik dalam ide-ide cerita yang diangkat dari kehidupan anak korban kekerasan dan eksploitasi seksual. Karena kehidupan keseharian mereka penuh dengan dramatik.

c. Membuat skrip cerita. Setelah alur cerita disusun, anak-anak diajak untuk membuat skrip cerita. Skrip cerita berisikan tentang dialog yang akan dipentaskan dalam pertunjukan teater. Skrip cerita ini disusun secara partisipatif.

3. Workshop Perencanaan menuju pertunjukan

Workshop ini digunakan untuk merumuskan langkah-langkah yang akan dilakukan untuk pementasan teater. Dalam workshop ini menghasilkan:

13 Teater Gidag Gidig adalah group teater yang didirikan pada 21 September 1976, di Surakarta dibawah kepemimpinan Bapak Hanindawan. 
a. Substansi pertunjukan. Yakni tentang Tujuan pementasan, sasaran penonton, lokasi pertunjukan, dan waktu pertunjukan.

b. Pembagian kerja Tim. Pembagian kerja tim disusun berdasarkan pada siapa melakukan apa. Kerja Tim dimulai dari penanggungjawab utama, tata panggung, kostum, pencari sponsor, dan informasi.

c. Casting. Casting dalam drama yang akan dimainkan adalah memilih pemain berdasarkan peran dan karakter yang dibutuhkan dalam suatu cerita.

d. Workplan. Workplan berisi kegiatan-kegiatan rinci menuju pertunjukan disertai penanggungjawab dan waktu. Di dalam workplan yang disusun menuju pertunjukan berisi tentang: pengurusan perijinan, jadwal kegiatan latihan dan sarasehan, mobilisasi sumberdaya, gladi bersih, pelaksanaan, dan evaluasi.

\section{Latihan dan Sarasehan Teater}

Latihan rutin dan sarasehan adalah 2 (dua) kegiatan yang selalu dilakukan secara bersama-sama. Latihan teater berisi tentang peningkatan kemampuan dalam bermain teater. Materi utama dalam latihan teater adalah olah vokal anak dan olah peran anak terhadap lakon yang akan mereka perankan. Anak-anak diberi tugas memainkan lakon satu persatu. Olah peran dengan memaikan lakon ini sangat penting bagi proses trauma healing. Melalui olah peran anak-anak dapat mengekspresikan ide atau mengungkapkan masalah-masalah yang selama ini mereka hadapi dalam bentuk ungkapan gerak seni teater.

Setelah latihan teater selesai, dilakukan sarasehan. Sarasehan ini dipandu oleh pendamping/konselor untuk melakukan refleksi cerita serta berdiskusi bagaimana rekomendasinya. Latihan teater dan sarasehan dilakukan setiap 2 (dua) mingguan. Saatsaat menjelang hari pertunjukan, latihan teater ditingkatkan frekuensinya menjadi setiap hari. Aktifitas latihan dan sarasehan teater ini dikelola oleh kelompok anak sendiri.

\section{Pementasan Teater}

Dalam program yang dijalankan oleh Yayasan KAKAK, telah dilakukan 6 (enam) kali pementasan teater kelompok anak. Yang menarik dalam perkembangan pementasan teater kelompok anak korban kekerasan dan eksploitasi seksual ini adalah terjadinya alih pengetahuan yang relatif cepat dalam berteater. Dua pentas diawal, pembuatan skenario pentas masih dibantu oleh pelatih teater (Gidag Gidig). Pada pentas yang ketiga sampai keenam, skenario cerita sudah dibuat oleh anak korban dengan berkonsultasi kepada pelatih teater. Bahkan, diantara anak korban kekerasan dan eksploitasi seksual ini sudah berani menjadi pelatih teater di tempat lain. 
"......tahun 2005 an kelompok teater Pelangi mulai berkembang mbak, anak-anak mulai menjadi pelatih/fasilitator pelatihan teater (di kandang Sapi), kita juga memilki beberapa skenario teater yang siap dipentaskan, kami membuat rencana program yang akan dijalankan. Hubungan kelompok teater dengan KAKAK adalah sebagai konsultatif, jadi kami melakukan pementasan diberbagai daerah tidak dengan ada pelatih tetapi dengan berkonsultasi dengan staf KAKAK, biasanya setelah kegiatan kami lakukan kami membuat laporan kegiatan dan laporan keuangan pementasan dilaporan ke KAKAK...."14

Dalam kesempatan tertentu, pernah juga melakukan pementasan kolaborasi antara anak korban dengan Forum Anak Surakarta. Mereka berteater bersama dengan mengangkat tema "Stop Kekerasan terhadap Anak."

Pentas teater dalam program ini bertujuan untuk melakukan peningkatan kesadaran publik (public awarreness) pentingnya perlindungan anak. Dalam ranah anak anak korban kekerasan dan eksploitasi seksual, pertunjukan teater adalah sarana membangun ruang ekspresi dan partisipasi anak korban dalam perlindungan anak.

Ciri khas pementasan teater anak korban kekerasan dan eksploitasi seksual ini pada pemilihan lokasi pertunjukan. Lokasi pertunjukkan bukan teater arena yang tertutup. Namun, lokasi pertunjukkan dipilih di kampung-kampung dengan nuansa terbuka dan berdekatan dengan lakon yang sedang dipertunjukkan. Masyarakat secara luas diperbolehkan untuk hadir menonton. Hal ini sesuai dengan tujuan program Yayasan KAKAK yakni membangun kesadaran publik,

\section{Sarasehan Pasca Pertunjukan.}

Dalam setiap pertunjukan, Yayasan KAKAK mengundang secara khusus resources Person yang memiliki kompentensi dalam isue anak. Resource Person (narasumber) ini akan membenah isue anak dalam sarasehan pasca pertunjukan bersama para penonton. Sarasehan dipandu oleh fasilitator Yayasan KAKAK.

\section{Evaluasi Pedampingan}

Evaluasi dalam program ini dilakukan secara bertahap, yaitu :

1. Evaluasi latihan dan sarasehan

Evaluasi ini dilakukan untuk melihat kontribusi latihan dan sarasehan yang sudah dilakukan dengan tujuan program.

“....saya merasa lebih berani dan akan ikut latihan terus biar bisa ikut pentas

14 Sholikah, Partisipasi Anak Pada Perlindungan Anak Yang Dilacurkan (AYLA); Studi Program Perlindungan Anak Di Yayasan KAKAK Di Surakarta. 
teater bersama teman-teman. Terimakasih kepada Yayasan KAKAK yang sudah mendampingi..." ${ }^{\prime \prime}$

Evaluasi yang dijalankan dengan menggunakan metodologi partisipatif. Fasilitator mengajak melakukan brainstorming tentang kemajuan latihan dan bagaimana perasaan mereka setelah latihan dan sarasehan.

2. Evaluasi Pentas

Evaluasi pentas,dilakukan setelah pentas. Ketua kelompok atau salah satu anggota yang terpilih memimpin evaluasi. Semua pemain dan pendukung ikut serta dalam diskusi evaluasi. Mereka merumuskan apakah hal-hal yang sudah baik yang sudah dilakukan serta apakah hal-hal yang masih harus ditingkatkan. Metode evaluasi dilakukan dengan brainstorming dan wawancara bersama dengan anak. Dalam evaluasi pentas ini, disebarkan juga poling kepada penonton yang hadir, untuk memberi masukan dan kesan pesan pentas.

3. Evaluasi program secara keseluruhan.

Evaluasi program secara keseluruhan dilakukan oleh Tim Program dengan melibatkan anak korban kekerasan dan eksploitasi seksual.

\section{Diskusi}

\section{Partisipasi Anak}

Dalam program ini, anak-anak korban berperan serta dalam proses perencanaan, implementasi dan evaluasi. Dengan membuat perencanaan sendiri, anak-anak akan merasa memiliki atau melu handarbeni program ini. Dengan begitu, anak-anak ikut bertanggungjawab atas sukses atau tidaknya program yang dilakukan oleh Yayasan KAKAK. Itulah salah satu inti partisipasi, yakni share tanggungjawab dan resiko.

Rasa melu handarbeni itu mewujud dalam peranserta anak-anak korban kekerasan dan eksplotasi seksual. Keaktifan mereka terlihat jelas dalam workshop menyusun materi pementasan, latihan teater, keterlibatan dalam pementasan, dan evaluasi kerja pementasan. Pelaksanaan sampai 6 (enam) kali pertunjukan menunjukkan tingkat partisipasi yang tinggi. Belum lagi kalau kita lihat materi pementasan. Dari 6 (enam) kali pertunjukan, 4 (empat) pertunjukan merupakan hasil karya anak-anak mulai dari them cerita, skrip, skenario, dan pengelolaan panggung.

Dari gambaran diatas, tergambar bahwa, dalam program "Teater, Sebagai Bentuk Partisipasi Anak dalam Pencegahan dan Trauma Healing Anak Korban Kekerasan dan Eksploitasi Seksual", anak-anak bisa membuat perencanaan program dan menjalankannya sendiri dan orang dewasa berperan dalam memberikan konsultasi dan 
membiarkan anak-anak menjalankan program mereka sendiri. Menurut tangga partisipasi Rogger Hart, tingkat partisipasi yang dicapai adalah level 7, yaitu anak diberi inisiatif dan diarahkan (Child - initiated and directed). Bisa juga dimasukkan dalam tangga ke 8 Child - initiated shared dicisions with adult, yang merupakan level level tertinggi dalam partisipasi anak, dengan model Hard. Indikator-indikator partisipasi dimana anak-anak dengan orang dewasa bersama-sama merencanakan, melaksanakan, dan memanage program sudah tergambar jelas melalui program yang dijalankan oleh Yayasan KAKAK.

\section{Trauma Healing}

Menurut ketua kelompok teater anak korban kekerasan dan eksploitasi seksual dalam satu sesi wawancara menyatakan:

"Tahun 2005-an kelompok teater Pelangi mulai berkembang mbak, anak-anak mulai menjadi pelatih/fasilitator pelatihan teater (di kandang Sapi), kita juga memilki beberapa skenario teater yang siap dipentaskan, kami membuat rencana program yang akan dijalankan. Hubungan kelompok teater dengan KAKAK adalah sebagai konsultatif, jadi kami melakukan pementasan diberbagai daerah tidak dengan ada pelatih tetapi dengan berkonsultasi dengan staf KAKAK, biasanya setelah kegiatan kami lakukan kami membuat laporan kegiatan dan laporan keuangan pementasan dilaporan ke KAKAK...."

Apa yang dikatakan oleh ketua kelompok teater tersebut menunjukkan bahwa teater sudah mampu mengembalikan trauma (trauma healing) yang diderita anak-anak korban kekerasan dan eksploitasi seksual. Bahkan anak-anak telah mencapai hasil yang lebih dibandingkan trauma, karena mereka telah mampu menjadi mentor (pelatih teater) bagi kelompok anak yang lain.

Menurut Nawangsih ${ }^{16}$, tahapan pemulihan yang dilakukan dengan menggunakan media teater ini dapat dilihat sebagai berikut adalah: (1) Anak-anak diberi kesempatan untuk menceritakan pengalamannya dengan dikemas menjadi skenario cerita (lakon teater); (2) Anak-anak diberi kesempatan untuk meluapkan tekanan emosinya, melalui gerakan dan vokal teater. Di dalam teater ini, anak-anak bisa berteriak, tertawa lepas bahkan berlari-lari. Yang ungkapan ini dikemas dalam sebuah adegan lakon teater; (3) Anak-anak diberi kesempatan untuk menyampaikan kekecewaan, harapan dan cita-cita mereka, yang dikemas dalam cerita teater; dan (4) Anak-anak diberi kesempatan untuk berekspresi dihadapan orang banyak, dengan tanpa rasa takut dan malu. Dalam beberapa pementasan, anak-anak menggunakan kostum tertutup, dengan menggunakan topeng. Hal ini untuk mendukung anak-anak yang masih belum punya keberanian. Namun, dalam beberapa pentas kemudian, mereka sudah berani tampil apa

16 Endah Nawangsih, "Play Therapy Untuk Anak-Anak Korban Bencana Alam Yang Mengalami Trauma (Post Traumatic Stress Disorder/Ptsd)." Psympathic: Jurnal Ilmiah Psikologi 1, no. 2 (2014): 164178. 
adanya tanpa rasa malu dan takut.

Untuk melihat manfaat penggunaan teater sebagai pendekatan truama healing terhadap korban anak korban kekerasan dan eksploitasi seksual, dapat diadaptasi dari keuntungan penggunaan play therapy model yang dikembangkan The Association for Play Therapy. Manfaat tersebut dapat dilihat sebagai berikut: (1) Mengatasi resistensi. Anak-anak korban lebih merasa tertarik dan bersedia mengikuti program. Anak-anak cukup terbuka menceritakan pengalaman, harapan dan cita-cita mereka. Hal ini memudahkan konselor dalam melakukan proses pendampingan; (2) Komunikasi. Melalui teater, memudahkan anak-anak korban mengkomunikasikan persoalan yang mereka hadapi dan anak-anak lebih leluasa mengekspresikan perasaan hati mereka; (3) Kompeten. Dengan bermain teater, ada banyak kompetensi yang dimiliki anak-anak, antara lain: kompetensi utnuk membuat skenario cerita, kompetensi untuk memerankan lakon teater, kompetensi untuk mengorganisir suatu kelompok; (4) Berpikir kreatif. Anak-anak termotivasi untuk berfikir kreatif dalam hal pembuatan skenario teater. Anak-anak juga terlibat dalam diskusi pemecahan masalah (problem solving) atas persoalan yang dialami; (5) Chatarsis. Melalui teater anak-anak bisa leluasa meluapkan emosinya, dengan ekspresi lakon teater. Mereka bisa berteriak, menangis, tertawa dan bahkan berlari-lari sesuai adegan yang diperankan. Yang dengan demikian dapat menyampaikan tekanan emosi yang dialaminya dengan lebih bebas, sehingga anak-anak bisa tumbuh dan berkembang secara optimal; (6) Abreaction. Dalam bermain teater, anak-anak diberi peran sesuai kisah mereka dan sesuai pilihan anak, sehingga anak-anak bisa menceritakan secara secara simbolis dengan ekspresi emosi yang tepat, pengalaman mereka baik yang sedih maupun yang menggembirakan; (7) Attachment formation. Dengan bermain teater, kesempatan anak-anak bertemu dengan konselor lebih intens dan terjadwal baik. Hal ini lebih mendekatkan lagi hubungan dan kepercayaan anak-anak kepada konselor. Dengan demikian, konselor akan lebih mudah dalam memberikan masukan dan intervensi terapi; (8) Emosi positif. Dengan bermain teater, anak-anak merasa lebih gembira karena bertemu dengan banyak orang. Merasa nyaman dan terbuka untuk bercerita dengan konselor. Mereka bisa melupakan pengalaman menyakitkan yang pernah dialami dan bisa menguasai emosi; (9) Menguasai ketakutan. Dengan banyak berlatih teater dan banyak bertemu dengan teman, konselor dan oranglain, anak-anak akan merasa aman, merasa sudah diterima kembali sebagaimana sebelum trauma mereka alami. Selain itu, beberapa keterampilan bermain teater akan dikuasai anak-anak; (10) Peningkatan hubungan. Melalui bermain teater dan melakukan pentas teater, anak-anak korban akan berkesempatan berinteraksi dengan banyak pihak, baik masyarakat, pemerintah atau para pemerhati hak anak. Hal ini mendukung anak-anak korban untuk diterima secara lebih baik di masyarakat. 


\section{Dampak Program}

Dampak program yang dikembangkan Yayasan KAKAK melalui teater anak ini dapat dijelaskan sebagai berikut:

1. Opini Stop Kekerasan dan Eksploitasi Seksual Anak yang semakin meluas

Dengan pementasan teater anak korban kekerasan dan eksploitasi seksual, memunculkan opini bahwa menjadi penting adanya perlindungan anak-anak dan eksploitasi seksual pada anak-anak adalah kejahatan. Hal ini diindikasikan dengan semakin banyaknya pembicaraan tentang pentingnya kesadaran publik atas perlindungan anak terkhusus perlindungan atas eksploitasi seksual.

2. Perubahan Kebijakan yang child friendly di Kota Surakarta

Tingginya Frekuensi pementasan teater anak korban kekerasan dan eksploitasi seksual memberikan sumbangan munculnya kebijakan yang child friendly di kota Surakarta. Beberapa kebijakan yang dapat diidentifikasi sebagai sumbangan program Yayasan KAKAK, antara lain: (1) Gagasan lahirnya Peraturan daerah perlindungan anak Kota Surakarta; (2) Munculnya forum-forum anak pada tingkat kalurahan; (3) Munculnya tim perlindungan anak dari kekerasan dan eksploitasi seksual di tingkat kota dan Kalurahan Kota Surakarta; dan (4) Dibangunnya taman pintar

3. Kembali ke jalan yang benar

Sejak awal Yayasan KAKAK berprinsip "tidak ada toleransi" atas pelacuran anak. Maka setiap usaha yang dilakukan berupaya untuk mengembalikan anak-anak ke jalan yang benar, yakni sesuai dengan prinsip Konvensi Hak Anak (KHA). Beberapa dampak program terkait hal ini adalah kembalinya beberapa anak ke jalan yang benar sesuai norma yang berlaku di wilayah kota Surakarta. Beberapa anak-anak yang sekarang sudah dewasa menekuni profesi sebagai: EO (event Organizer), MC (Master of Cheremony), membuka bisnis konfeksi, dealer mobil, dan menjadi ibu rumah tangga yang baik.

\section{Kesimpulan}

Anak-anak haruslah dipandang sebagai manusia seperti layaknya manusia dewasa. Mereka punya hak-hak yang harus dilindungi, dipenuhi, dan dipromosikan. Partisipasi anak dalam program-program yang ditujukan untuk anak-anak haruslah mutlak dilakukan. Karena tanpa partisipasi murni, setiap program pembangunan yang diperuntukan bagi anak-anak hanyalah sebuah program artifisial, dan akhirnya tidak akan menghasilkan apapun.

Teater merupakan strategi yang jitu dalam mendorong partisipasi anak, khususnya anak-anak korban kekerasan dan eksploitasi seksual. Teater dalam menjadi 
penawar (katarsis) bagi anak-anak yang mengalami trauma. Karena melalui teater, anak-anak dapat mengungkapkan perasaan tertekan dan aspirasinya dapat didengar orang. Melalui teater, anak-anak juga mampu mengenali jati dirinya. Dengan begitu, mereka akan mudah untuk diajak kembali.

\section{Daftar Referensi}

Erlyana, Yana. “KAJIAN KAMPANYE SOSIAL HEMAT AIR.” Rupa Rupa 4, no. 2 (2017).

Hart, R A. "Children's Participation: From Tokenism to Citizenship (UNICEF International Child Development Centre. Spedale Degli Innocenti. Firenze, Italy)" (1992).

Menteri Negara Pemberdayaan Perempuan dan Perlindungan Anak Republik Indonesia. Peraturan Menteri Negara Pemberdayaan Perempuan Dan Perlindungan Anak Republik Indonesia, Nomor 3 Tahun 2011, Tentang Kebijakan Partisipasi Anak Dalam Pembangunan. Indonesia, 2011.

Nawangsih, Endah. "Play Therapy Untuk Anak-Anak Korban Bencana Alam Yang Mengalami Trauma (Post Traumatic Stress Disorder/Ptsd)." Psympathic: Jurnal Ilmiah Psikologi 1, no. 2 (2014): 164-178.

Presiden Republik Indonesia. Keputusan Presiden RI No. 87 Tahun 2002 Tentang Rencana Aksi Nasional (RAN) Penghapusan Eksploitasi Seksual Komersial Anak. Indonesia, 2002.

-_- Undang-Undang Republik Indonesia Nomor 14 Tahun 2009 Tentang Pengesahan Protokol Untuk Mencegah, Menindak, Dan Menghukum Perdagangan Orang, Terutama Perempuan Dan Anak-Anak, Melengkapi Konvensi Perserikatan BangsaBangsa Menentang Tindak Pidana Transnasio. Indonesia, 2009.

- - - Undang-Undang Republik Indonesia Nomor 35 Tahun 2014 Tentang Perubahan Atas Undang-Undang Nomor 23 Tahun 2002 Tentang Perlindungan Anak. Jakarta, Indonesia, 2014.

Setyawan, Davit. “Lindungi Anak Indonesia Dari Kekerasan Seksual." Komisi Perlindungan Anak Indonesia.

Sholikah, Nining. Partisipasi Anak Pada Perlindungan Anak Yang Dilacurkan (AYLA); Studi Program Perlindungan Anak Di Yayasan KAKAK Di Surakarta. Surakarta, 2008.

Team Peneliti UNICEF Indonesia. Partisiasi Anak Indonesia: Harapan Dan Impian. Jakarta, 2005.

United Nations. Convention on the Rights of the Child Text, 1989.

Wajdi, Muh Barid Nizarudin. "Trauma Healing Pada Penderita Depresi Di Nganjuk." Janaka, Jurnal Pengabdian Masyarakat 1, no. 2 (2019): 27-32. 